\title{
ON THEIR WAY OUT
}

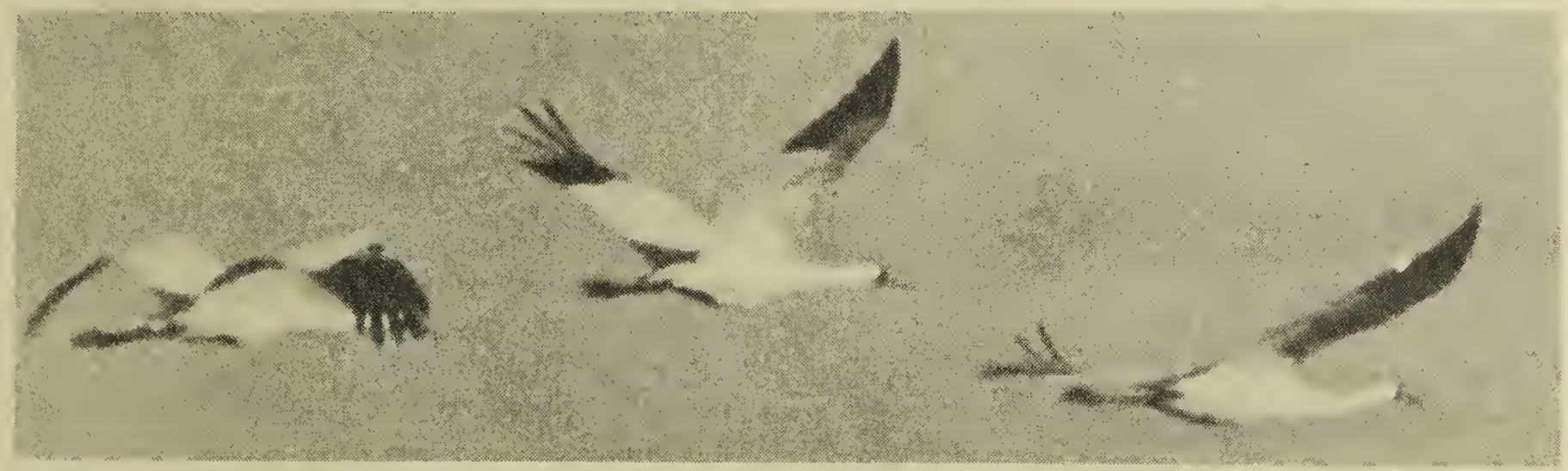

The remarkable pictures shown on this and the previous page of three Whooping Cranes, winging their way to the Sunny South, were taken at Herbert, Saskatchewan, by F. W. Lahrman, artist, photographer and field worker with the Saskatchewan Museum of Natural History. The Associated Press has called the larger picture on the left, taken on November 5 , as "the most exceptional picture of this week." It has been printed in all the larger papers in Canada and United States. "The Blue Jay" is the first to print the other two.

Mr. Fred Bard, Director of the Museum, who was responsible for the trip to Herbert, also took moving pictures in color of the birds as they passed over the two naturalists, crouched in a ditch. In the following article $\mathrm{Mr}$. Bard tells of their experiences.

Mr. Lahrman, using an Exakta camera with a $300 \mathrm{~mm}$ telephoto lens snapped the birds at $1-500$ of a second, at $f, 6.3$.

\section{A MEMORABLE EXPERIENCE}

\author{
By FRED G. BARD
}

\section{Director, Provincial Museum of Natural History}

On Tuesday, November 3rd, the appearance of three Whooping Cranes was reported from the Herbert District by Mr. A. H. Zacharais. The next day a second telephone call reported that the birds had been there for several days and that they were undoubtedly Whooping Cranes. I then decided to hurry out as soon as possible to get a look at these rare birds.

As we drove west the short November day rapidly drew to a close and we began to have visions of the birds leaving without our having an opportunity of seeing them. There would be no opportunity of visiting the area this day in daylight.

In the quiet of the country hotel at 6.00 a.m., Fred Lahrman and I hit the deck and by 6.30 we had selected a pointage of vantage overlooking the lake. Fifteen minutes later we were on this point surveying Francis Lake, which lay before us. The birds were already on the stubble as dawn broke. We had left Herbert too early for breakfast, so as we sat there watching the birds, I remembered my thermos of tomato soup and poured this out, sharing it with Lahrman. We were well ovel a quarter of a mile from the birds and the light was not too good, but we could see what we were doing. Lahrman remarked how good the soup was, and remembering about mine I looked down only to find that I had spilled it in the excitement of watching the birds. But who could think about stomachs when witnessing such a wonderful sight on such a wonderful day

Gradually the sun rose and bathed the golden stubble and these im- 


\section{A MEMORABLE EXPERIENCE}

(Continued from Page 7)

as we were and, in a very short time, the news soon spread around town. They were indeed the rare and beautiful Whooping Cranes. By this time too, we had struck the acquaintance of Tim Sue Thom, the young son of the proprietor who was keenly interested in the outdoors. He had already edited some material for the High School paper and was well on the way to becoming an advocate for the protection of the Whooping Cranes. He asked if he might go with us. We were delighted for we had obtained our pictures, and there would still be a chance for him to see the birds. It gave us an opportunity to acquire the rest of the material we wanted that afternoon and, by the time the sun fell behind the hills in the west, our young friend had spent an afternoon with the Whooping Cranes and, while no further pictures were obtained, we felt that the day was as full as it could be. With a prayer on our lips, we left these beautiful creatures, hoping they would certainly make it for years to come.

We returned to Regina that same evening and, as a finale to the splendid co-operatior given by the people of Herbert, we promised to provide them with photographs of the occasion.

The next day I received a telephone call from Ralph Steuck, the Abernethy naturalist. His interest was so great that he decided to drive into Regina, following a show to the people of Cupar. I am happy that he and Fred Lahrman were able to drive to Herbert, early Saturday morning.

The day was spent in searching the area-but the birds had gone, due no doubt to the sudden change in the weather. By this time the public interest was so high in Herbert that Ralph decided, as a mark of appreciation for the interest and protection afforded the rare birds, to put on a show of nature movies.

The accompanying photographs are unusual ones. The larger one of the sequence, like the other two, was taken by Fred Lahrman. To me, it is the outstanding photograph of all. When you consider that it was taken in this vast area where it was only a chance in a million the birds would come close enough for such a shot, the extreme good fortune is apparent. I am happy that such a beautiful photograph was taken by one who so fully appreciates the real significance of the value of these rare creatures.

\section{WASCANA VALLEY}

\section{J. H. TAYLOR, Regina}

Far too few Regina persons realize that within a few miles of the city Wascana runs into a beautiful wooded valley. There in late summer trees and shrubs are in full leaf. Saskatoons, black currants, raspberries, gooseberries and pin cherries are either ripe or ripening.

Late summer flowers are in bloom. In July and August yellow is predominant color, cone flowers leading the parade. Wild currant, a late blooming shrub, is now in full flower. It has delightful pink blossom clusters and an exquisite perfume. Bergomot, which oldtimers dried for winter use, vies with its yellow neighbors in quantity and beauty. This is a miniature mauve chrysanthemum.

Young fluffy horned owls still wobbly in their flight wing from tree to tree. Shyer birds, brown thrashers, blackbilled cuckoos, arctic towhees and catbirds love this valley and make it their summer home. There are several beaver dams. Results of beaver logging operations may be observed. At a quiet hour in the evening one sometimes sees the busy fellows. Tracks of deer are plentiful though one seldom lights upon the beautiful creatures themselves.

From the banks flow some springs. One near the old crossing of buffalo hunting days seems to have mineral properties. Moss on its edges petrifies. Settlers of the neighborhood tell that petrified toads and frogs may be found by doing a little spade work. And for the geologist, scattered shale rocks on the upper hillside yield many fossils.

All this may be found on a late summer day almost within sight of Regina. 